\title{
Feeding Habits of the Southern Australian Garfish Hyporhamphus melanochir: A Diurnal Herbivore and Nocturnal Carnivore
}

\author{
A. I. Robertson ${ }^{1}$ and D. W. Klumpp ${ }^{2}$ \\ Department of Zoology^and Botany², University of Melbourne, Parkville, Victoria 3052, Australia
}

\begin{abstract}
The diet of Hyporhamphus melanochir underwent shifts from green eelgrass (Zosteraceae) tissue during the day to mainly benthic dwelling amphipods and other invertebrates at night. The shifts occurred sharply at dawn and dusk and were observed in all size groups of the fish (range of lengths 10.0 to $29.8 \mathrm{~cm}$ ). H. melanochir probably took detached eelgrass leaves from the water column during the day but may also have grazed live eelgrass. Feeding on benthic dwelling amphipods was facilitated by nocturnal vertical migration of these prey. Animals, particularly crustaceans, but also insects, appear to be the preferred prey of garfish. Eelgrass is probably consumed during the day because crustacean prey are rare in the water column at that time. The feeding strategy of $H$. melanochir appears to be an adaptation to diel changes in food availability as well as the fishes' metabolic requirements.
\end{abstract}

\section{INTRODUCTION}

Many members of the family Hemiramphidae, the garfish or half-beaks, are associated with shallowwater seagrass meadows, and seagrass tissue forms a major portion of their diets (e. g. Thomson, 1959; Randall, 1967; Carr and Adams, 1973; Coetzee, 1979 cited in Day et al., 1981; McRoy and Helfferich, 1980).

In Australia, much qualitative information on the diet of the southern garfish Hyporhamphus melanochir suggests that it is a true herbivore, feeding primarily on eelgrass (Zosteraceae) (e.g. Ling, 1958; Thomson, 1959; Wood, 1959; Scott et al., 1974). However, it is difficult to reconcile the short, straight gut of $H$. melanochir with a truly herbivorous existence, since large relative gut lengths are necessary for the digestion of plant tissue in most obligate herbivorous fish (e.g. Ogden and Lobel, 1978; Hofer and Schiemer, 1981).

As a first step to understanding the feeding and nutrition of Hyporhamphus melanochir, this paper

A.I.R.: CSIRO, Division of Fisheries Research, P.O. Box 20, North Beach, W. A. 6020, Australia

D.W.K.: Dept. of Zoology, University of Cape Town, Rondebosch, 7700, South Africa

(c) Inter-Research/Printed in F. R. Germany deals with its natural diet, emphasizing diel dietary shifts and the relationship between fish size and diet. The study shows that the feeding strategy of $H$. melanochir is more complex than previously reported.

\section{METHODS}

Most sampling of Hyporhamphus melanochir was undertaken at Crib Point, Western Port Bay $\left(38^{\circ} 21^{\prime} \mathrm{S}\right.$, $145^{\circ} 13^{\prime} \mathrm{E}$ ), while a detailed 24 -h study of dietary shifts was carried out at nearby Duck Point, Corner Inlet $\left(38^{\circ} 47^{\prime} \mathrm{S}, 146^{\circ} 15^{\circ} \mathrm{E}\right)$ (Fig. 1). Both areas are characterized by extensive intertidal and shallow subtidal mudflats which support large meadows of eelgrass (Zostera muelleri and Heterozostera tasmanica). A detailed description of the major study site at Crib Point is given in Robertson (1977).

A beach seine net $(50 \times 1.5 \mathrm{~m}, 1.27 \mathrm{~cm}$ mesh) was used to capture fish. At Crib Point a number of nettings (between 2 and 9) were undertaken during day and night on each of 16 sampling dates between 1974 and 1976 as part of a large study of the fish fauna associated with eelgrass meadows (Robertson, 1980). Garfish were not captured on all sampling dates and there 


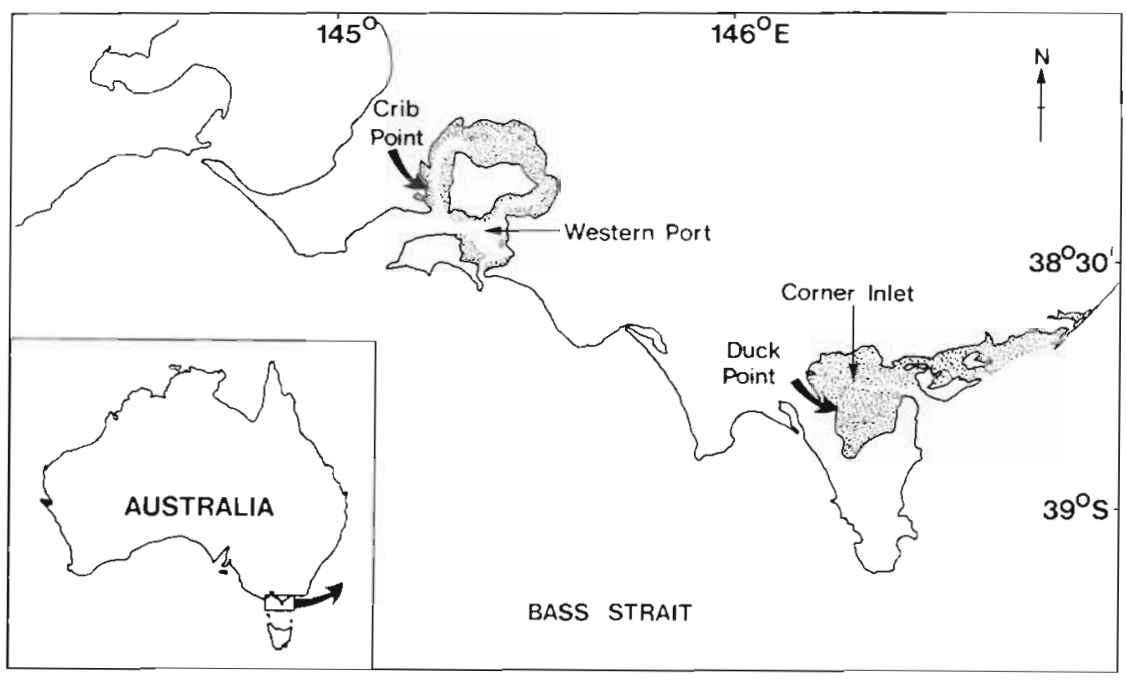

Fig. 1. Location of Crib Point and Duck Point study sites in south-eastern Australia. Stippling: extent of shallow seagrass-bearing mudflats in the 2 areas were insufficient fish to give a reliable idea of seasonal dietary shifts. However, by pooling all individuals (134), enough data were available for an analysis of day and night diets for different size groups of fish.

Once captured, fish were immediately placed in a $10 \%$ formalin seawater solution after the body walls of large individuals were opened to allow rapid preservation of gut contents. In the laboratory the length to caudal fork (LCF) was recorded for each fish, the gut removed and the gut contents placed in a Petri dish. After sorting, using a dissecting microscope, the representation of each food category was scored both as percentage occurrence and percentage volume (Robertson, 1977).

Details of diel shifts in diet were investigated by analysing the gut contents of fish captured at 3-h intervals during a 24 - $h$ period in November 1981 at the Corner Inlet study site. Between 10 and 15 fish (14 to $18 \mathrm{~cm}$ LCF) from each sample were retained for analyses of stomach contents. For each fish the relative position and proportions (by dry weight) of eelgrass and animal remains in the gut as well as the fullness (total weight of food $\times 100 /$ weight of fish) were recorded.

\section{RESULTS}

\section{Size and Age}

The size distribution of all fish captured at Crib Point was similar for night and day samples (Fig. 2). In South Australia, male and female Hyporhamphus melanochir mature at 26 and $25 \mathrm{~cm}$ LCF respectively (Ling, 1958). If the same is true in Victoria then most specimens captured in this study were immature. Reference to length at age data in Ling (1958) indicates that most fish were between 1 and 3 yr of age when captured.
However recent observations on $H$. melanochir in Western Australia would suggest that the smallest fish captured in this study (10 to $11 \mathrm{~cm}$ ) belonged to the $0+$ age group (R. Lenanton, pers. comm.).

\section{Diet and Feeding Behaviour}

There was a clear diel change in the diet of Hyporhamphus melanochir (Table 1). During the day, green eelgrass tissue was present in the guts of $93 \%$ of fish $_{i}$ it constituted almost $70 \%$ of the total volume of food consumed. Insects were also important prey, and amphipods and natantian larvae made up most of the remaining food. In contrast, amphipods ( 3 main spp.) were by far the most important prey at night. Eelgrass tissue was consumed by one third of fish and was only $18 \%$ of the total volume of food. Polychaetes also contributed significantly to the total volume of the diet, but were only consumed by a small number of fish (Table 1).

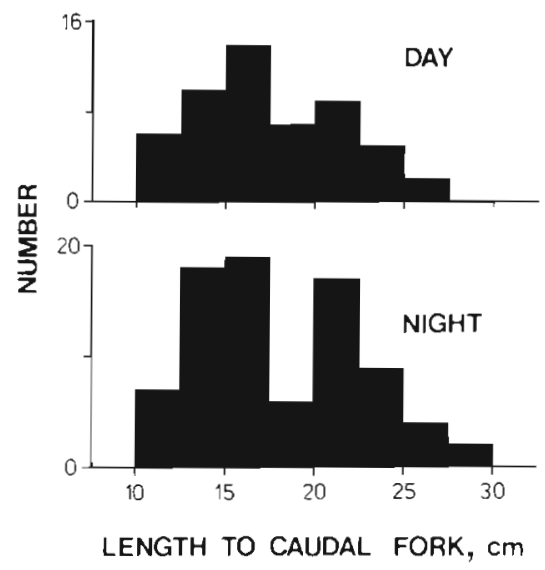

Fig. 2. Hyporhamphus melanochir. Size distribution of fish captured during day $(n=53)$ and night $(n=81)$ at Crib Point between 1974 and 1976 
(Fig. 3). Many of these polychaetes were epitokous nereids, indicating that they may have been consumed while swimming in the water column. Eelgrass was only a small portion of the nocturnal diet of most size groups.

The detailed, diel feeding study revealed that dietary shifts between plant and animal foods were more clear cut than the previous data suggested (Fig. 4). Fish

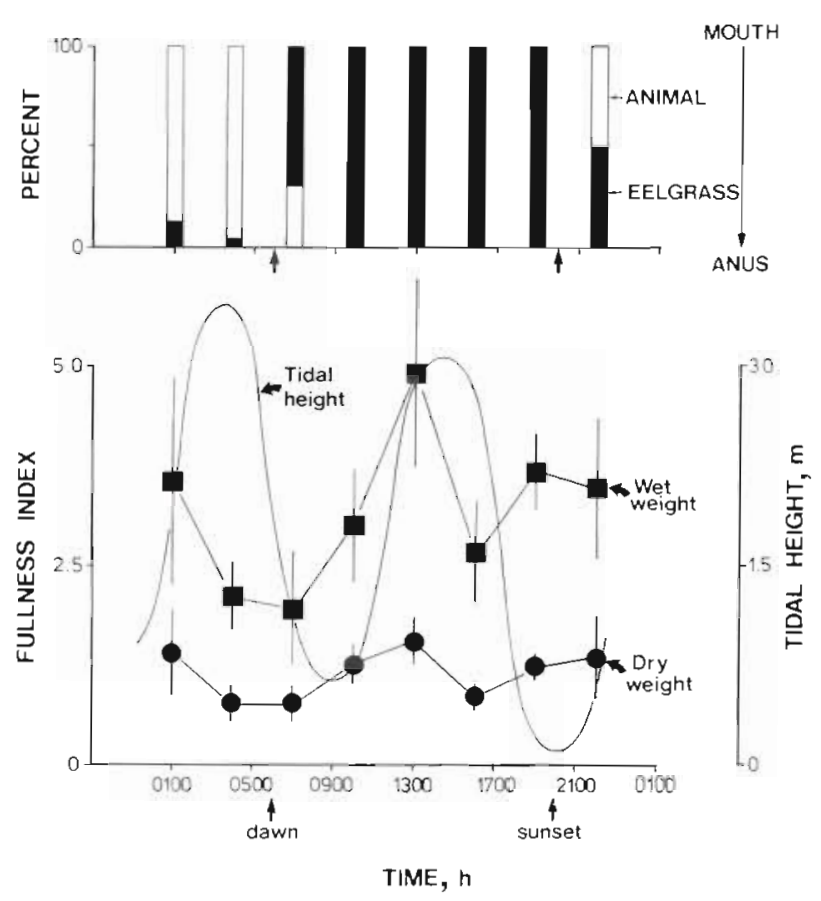

Fig. 4. Hyporhamphus melanochir. Relative position and mean percentage mass of food (eelgrass and animal material) in the guts of fish sampled every 3 h during a 24 -h period (animal food consisted mainly of amphipods and isopods); and mean $( \pm 1 \mathrm{SD})$ fullness index of the same fish in relation to time and tidal height. Fullness indices calculated on the basis of both wet and dry weights

began to feed on eelgrass immediately after dawn, but at the first daylight sampling fish still retained crustacean material in their hindguts. Fish contained only eelgrass until sunset, after which feeding on crustaceans began, but some eelgrass was found in the hindgut of fish during the night. Nearly all eelgrass was gone before dawn. These data suggest that in the earlier, less detailed study of the diets, samples which were taken say, early in the morning would have contained animal material, although fish were only feeding on eelgrass at that time. Similarly samples taken during the night would contain eelgrass in the hindgut when fish were feeding only on crustaceans.

The plot of the fullness index during the 24 -h period showed a peak at $1300 \mathrm{~h}$, on a flood tide, and a high point at $0100 \mathrm{~h}$ on the previous flood tide. Enough water remained over the eelgrass flats for feeding to continue during low tide periods (Fig. 4).

\section{DISCUSSION}

The marked diel dietary shift from eelgrass to mainly amphipods has not previously been reported for Hyporhamphus melanochir (e.g. Thomson, 1959; Wood, 1959) or for other hemiramphids, although omnivory among other members of the family is well known (e.g. Randall, 1967; Carr and Adams, 1973).

Garfish and half-beaks are presumed to be midwater and surface feeding fish. (Lagler et al., 1977) and have been observed taking seagrass leaves which are detached and floating near the waters surface (Carr and Adams, 1973). This may also be true for Hyporhamphus melanochir. However, eelgrass in the foregut is always green and fish at the Corner Inlet study site were observed moving amongst living eelgrass plants near the bottom, suggesting that they may bite off living leaves as well.

A seeming paradox is how Hyporhamphus melanochir feeds on benthic dwelling amphipods during the night. The answer probably lies with the vertical migratory movements of the 3 major amphipod species consumed by $H$, melanochir. Previously it has been shown that large numbers of the amphipods Paradexamine churinga, Tethygeneia nalgo and Metaphoxus W. P. sp. 1 move up into the water column during the night at the Crib Point study site, presumably to locate mates or to disperse, and they are then consumed by $H$. melanochir and other mid-water feeding fish (Robertson and Howard, 1978). Fish in the present study were captured in all seasons throughout a 3-yr period; this suggests that vertical migration among these amphipods is not limited to the summer period reported in Robertson and Howard (1978). The suddenness of the dietary shift is probably explained by the immediate activity of amphipods and other invertebrates above the eelgrass canopy after sunset (Robertson and Howard, 1978).

Some small changes in feeding habits are often superimposed on the more general pattern. For instance insects may become abundant on the water surface at some times during the year (see 'Results'), and are then often taken by Hyporhamphus melanochir during the day. Natantian and brachyuran larvae are also seasonally abundant in the water column (Robertson and Howard, 1978) and are sometimes included in the daytime diet. Likewise, at night, epitokous polychaetes were sometimes consumed by some size groups of $H$. melanochir, when polychaetes were presumably swimming in the water column. In addition, crustacean prey consumed at night at the Corner 
Inlet study site contained epiphytal isopods which are not known to swim in the water column. This suggests that perhaps some benthic feeding also occurs.

Gut-fullness data suggests that the period of maximum food consumption was during flood tides, irrespective of night or day. Rising tides probably float many detached eelgrass leaves out of eelgrass meadows, and thus make this food source more available to mid-water and surface feeding Hyporhamphus melanochir during the day. Amphipods rise into the water column on flood tides at night and their numbers decrease on falling tides (Robertson and Howard, 1978), thus favouring more intensive feeding during noctumal rising tides. It is reasonable to assume that floating or attached eelgrass leaves are equally abundant throughout a 24-h cycle. If so, the inclusion of animal prey (particularly crustaceans) in the daytime diet during periods when they became available in the water column suggests that animals, not eelgrass, were the preferred food of $H$. melanochir.

The feeding strategy of Hyporhamphus melanochir must also be viewed in the light of its metabolic demands as well as the pattern of food availability. Our preliminary examinations of eelgrass in the hindgut suggest that maceration of the tissue by the pharyngael teeth aids the digestion of cell contents, but the very small relative gut length and the estimated passage time for eelgrass $(7.5 \mathrm{~h},-2030$ to 0400 ; Fig. 4) probably do not allow much cellulose digestion to take place (e. g. Kapoor et al., 1975; Hofer and Schiemer, 1981). Green eelgrass tissue has a carbon to nitrogen ratio much higher than that required to support animal growth (e. g. Phillips and McRoy, 1980) and since so little of the ingested eelgrass appears to be assimilated by $H$. melanochir it is probable that the consumption of animal tissue is necessary to balance the fishes' nitrogen budget.

\section{LITERATURE CITED}

Carr, W. E., Adams, C. A. (1973). Food habits of juvenile marine fishes occupying seagrass beds in the estuarine zone near Crystal River, Florida. Trans. Am. Fish. Soc. 102: $511-530$

Day, J. H., Blaber, S. J. M., Wallace, J. H. (1981). Estuarine fishes. In: Day, J. H. (ed.). Estuarine ecology with particular reference to southern Africa. A. A. Balkema, Rotterdain, pp. 197-222

Hofer, R., Schiemer, F. (1981). Proteolytic activity in the digestive tract of several species of fish with different feeding habits. Oecologia 48: 342-345

Kapoor, B. G., Smit, H., Verighina, I. A. (1975). The alimentary canal and digestion in teleosts. Adv. mar. Biol. 13: $109-239$

Lagler, K. F., Bardach, J. E., Miller, R. R., Passino, D. R. M. (1977). Ichthyology, 2nd ed., John Wiley and Sons, New York

Ling, J. K. (1958). The sea garfish, Reporhamphus melanochir (Cuvier and Valenciennes) (Hemiramphidae), in South Australia: breeding, age determination, and growth rate. Aust. J. mar. Freshwat. Res. 9: 60-105

McRoy, C. P., Helfferich, C. (1980). Applied aspects of seagrasses. In: Phillips, R. C., McRoy, C. P. (eds.) Handbook of seagrass biology. Garland STPM Press, New York, pp. $297-343$

Ogden, J. C., Lobel, P. S. (1978). The role of herbivorous fishes and urchins in coral reef communities. Env. Fish. Biol. 3: $49-63$

Phillips, R. C., McRoy, C. P. (eds.) (1980). Handbook of seagrass biology, Garland STPM Press, New York

Randall, J. E. (1967). Food habits of reef fishes of the West Indies. Stud. Trop. Oceanogr. Univ. Miami. 5: 665-847

Robertson, A. I. (1977). The ecology of juvenile King George whiting Sillaginodes punctatus (Cuvier and Valenciennes) (Pisces: Perciformes) in Western Port, Victoria. Aust. J. mar. Freshwat. Res. 28: 35-43

Robertson, A. I. (1980). The structure and organization of an eelgrass fish fauna. Oecologia 47:76-82

Robertson, A. I., Howard, R. K. (1978). Diel trophic interactions between vertically migrating zooplankton and ther fish predators in an eelgrass community. Mar. Biol. 48: $207-213$

Scott, T. D., Glover, C. J. M., Southcott, R. V (1974). The marine and freshwater fishes of South Australia. Australian Government Printer, Adelaide

Thomson, J. M. (1959). Some aspects of the ecology of Lake Macquarie, N. S. W., with regard to an alleged depletion of fish. IX. The fishes and their food. Aust. J. mar. Freshwat. Res. 10: 365-374

Wood, E. J. F. (1959). Some east Australian sea-grass communities. Proc. Linn. Soc. N. S. W. 84: 218-226 